\title{
Geochemical Characteristics of Active Backarc Basin Volcanism at the Southern End of the Mariana Trough
}

\author{
Harue Masuda and Patricia Fryer
}

\begin{abstract}
Major and minor chemistry, $\mathrm{Sr}, \mathrm{Nd}$ and $\mathrm{Pb}$ isotope ratios, water content and hydrogen isotope ratios of the backarc basin volcanic rocks taken from the active spreading ridge and surrounding area between $12^{\circ} 40^{\prime} \mathrm{N}$ and $13^{\circ} 15^{\prime} \mathrm{N}$ in the southern part of the Mariana Trough indicate a complex regional interplay of suprasubduction-zone magmatic sources.

In this area, active backarc spreading occurs along the eastern side of the Mariana Trough, and discrete seamounts align on two parallel chains east of the backarc spreading center. The spreading-center rocks originated from a typical mid-ocean ridge basalt (MORB)-like source, influenced progressively southwestward by proximity to the arc magmatic source and range from basaltic to dacitic in composition. The volcanic rocks from the seamount chains are explained by the mixing of two types of magmatic sources; one is originally a depleted mantle similar to the arc source for magmas farther north and the other is the MORB-like source of the spreading ridge rocks. The influence of the arc source on magma composition of the seamount chains is higher north of $13^{\circ} \mathrm{N}$, indicating heterogeneity of the mantle wedge in this region and the merging of the two sources toward the southwest.
\end{abstract}

Keywords

Arc volcanisms $•$ Back arc spreading $•$ Hydrogen isotopes $•$ Major and minor element chemistry $\bullet$ Mariana Trough $\bullet$ Submarine volcanoes

\subsection{Introduction}

As an active subduction factory, where the formation of arc/ continental and oceanic crust can be observed, the Mariana convergent plate margin is one of the best documented intraoceanic subduction systems. The backarc spreading forming the Mariana Trough occurs in arc crust that has

The online version of this chapter (doi:10.1007/978-4-431-54865-2_21) contains supplementary material, which is available to authorized users.

H. Masuda $(\bowtie)$

Department of Geosciences, Osaka City University, 3-3-138,

Sugimoto, Sumiyoshi-ku, Osaka 558-8585, Japan

e-mail: harue@sci.osaka-cu.ac.jp

P. Fryer

Hawaii Institute of Geophysics and Planetology, University of Hawaii, 1608, East-west Road, Post 504Honolulu, HI 96822, USA been thinned by extension related to subduction and rollback of the Pacific Plate (Karig 1971; Hussong and Uyeda 1981). Because contamination by arc/continental crust and subducting sediments is minimal in this intraoceanic setting, the Mariana Trough is an ideal location to study material cycling and its relation to magmatism in a convergent margin.

Early petrological and geochemical studies of backarc basin rocks of the Mariana Trough concentrated on the central part of the basin at about $18^{\circ} \mathrm{N}$, where the backarc basin is widest (e.g., Hart et al. 1972; Hawkins 1977; Fryer et al. 1981; Natland and Tarney 1981; Hawkins et al. 1990). Subsequent studies extended to the northern area between $19^{\circ}$ and $24^{\circ} \mathrm{N}$, where the active backarc opening terminates where the active Mariana ridge and remnant West Mariana ridge meet (e.g., Jackson 1989; Stern et al. 1990; Hickey-Vargas 1991). These were followed by studies of the southern area, between $18^{\circ}$ and $15^{\circ} \mathrm{N}$ (Gribble et al. 1996). Documentation 
of the southern Mariana Trough also started in the 1990s (e.g., Johnson et al. 1993; Fryer et al. 1998). A synthesis effort to characterize the arc and backarc composition of the Mariana system on a regional basis as relates to tectonic history of the arc was presented in Pearce et al. (2005).

In this chapter, the geochemical features of the volcanic rocks from the backarc spreading center and discrete chains of volcanoes in the Mariana Trough south of $13^{\circ} 40^{\prime} \mathrm{N}$ are characterized based on major and trace elements and isotopic compositions. Our data provides a more detailed look at a part of the backarc basin that is different both morphologically and compositionally from the rest of the basin and that lies in a part of the basin influenced by unusual tectonic processes. We discuss the initiation process of backarc opening in this area in relation to the fluids responsible for the magmagenesis and the local tectonic processes.

\subsection{Geological Background and Sampling Locations}

\subsubsection{Bathymetry and Tectonic Setting}

The backarc opening of the Mariana Trough has been presumed to have started between the active Mariana and remnant West Mariana arcs at between 5 and $10 \mathrm{Ma}$ from the center of the trough (Hussong and Uyeda 1981; Karig 1971; Bibee et al. 1980; Eguchi 1984; Yamazaki and Stern 1997; Seama et al. 2001). The opening of the northern area was suggested to have started between 2.5 and $3.5 \mathrm{Ma}$ from $\sim 22^{\circ} \mathrm{N}$ and propagated northward (Yamazaki et al. 1993; Martinez et al. 1995).

The Mariana backarc spreading center between $14^{\circ}$ to $22^{\circ} \mathrm{N}$ shows generally well-developed rift valley morphology, typical of slow spreading centers such as the Mid-Atlantic Ridge (MAR). The southern Trough area south of $14^{\circ} \mathrm{N}$ (Fig. 21.1) is topographically different from the rest of the basin. The area is generally shallower by about $1 \mathrm{~km}$. Early explanations for such shallow seafloor included diffuse spreading (Hawkins 1977; Smoot 1990), but detailed mapping and sonar imaging (Martinez et al. 2000) led to the discovery that a well-organized spreading center, the Malaguana-Gadau Ridge (MGR hereafter, and in Fig. 21.1). The MGR is located well to the eastern side of the basin and has the typical morphology of fast spreading oceanic ridges like the East Pacific Rise (EPR) (i.e., Kasahara et al. 1994; Fryer et al. 1998) (Fig. 21.1). Such a fast-spreading-ridge morphology formed via higher magmatic activity in this part of the basin than elsewhere (Martinez et al. 2000). Gravity anomaly surveys supported this interpretation; the crust of this area is about 5.9-6.9 km thick, thicker than that of other areas of Mariana Trough (Kitada et al. 2006).
Fig. 21.1 Studied area and locations of rock sampling MGR: active spreading ridge; Red dotted lines: Discrete seamount chains (DSC) (PMVC and FNVC indicate west and east lines respectively); symbols indicating sample locations categorize the geology and sediments as follows. Blue circle: northern segment of MGR; blue square: southern segment of MGR; red and purple diamonds: offridge axis seamount; red reverse triangle: northern segment of DSC; purple normal triangle: southern segment of DSC

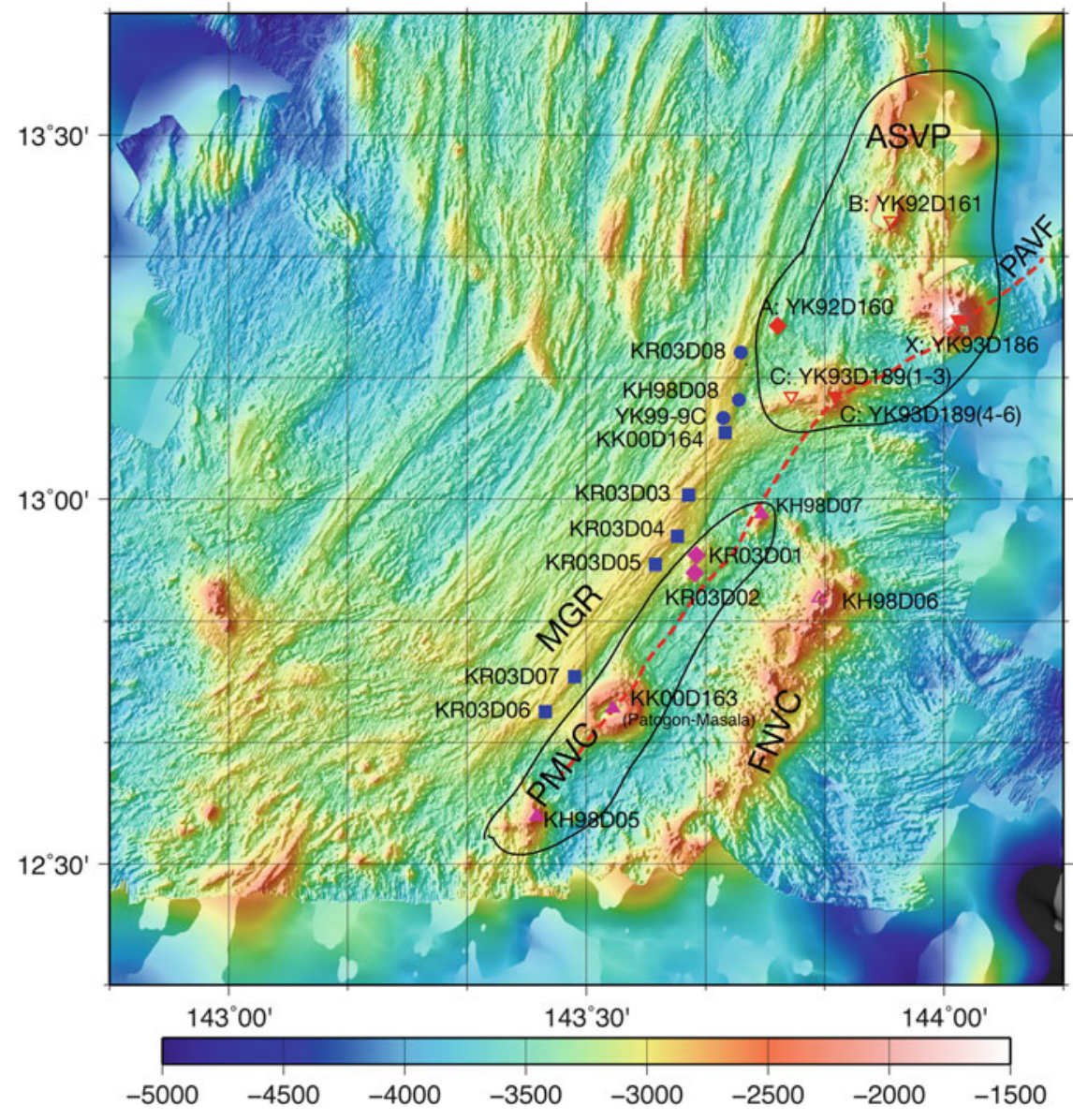


In the southern part of Mariana Trough, opening of the backarc basin was presumably accommodated by stretching of the Mariana forearc associated with accretion of basaltic intrusion/eruption at 3.7-2.7 Ma. This was recently confirmed at the Southeast Mariana Forearc Rift (Ribeiro et al. 2013a), and spreading was presumed to have started 3-3.5 Ma. The spreading center is suggested to have jumped to the present position from $20 \mathrm{~km}$ west (Seama et al. 2001). The volcanic activity of the current spreading center was activated during Brunhes Chron (0.7 Ma to present) (Martinez et al. 2000; Seama et al. 2001). Although the ridge shows the EPR-type spreading ridge topography and the spreading rate is higher in the southern Trough than farther north, the rate is still not as great as the EPR. Estimates range $<60$ to $40-45 \mathrm{~mm} /$ year based on magnetic anomalies (Martinez et al. 2000) and $\sim 45 \mathrm{~mm} /$ year at $13^{\circ} \mathrm{N}$ estimated by GPS measurement at Guam (Kato et al. 2003).

Based on submersible and ROV observations, volcanic activity in the northern half of the MGR from $13^{\circ} 12^{\prime} \mathrm{N}$ seemed to be quiescent at present, since all the sites observed were thinly covered with sediments and only inactive hydrothermal fields were observed. Although much of the MGR south of $13^{\circ} 12^{\prime} \mathrm{N}$ is volcanically active, the most active area is between $13^{\circ} 05^{\prime}$ and $13^{\circ} 12^{\prime} \mathrm{N}$ (Mitsuzawa et al. 2000). It is notable that a magma chamber was found by seismic reflection data beneath the spreading ridge at $13^{\circ} 05^{\prime} \mathrm{N}$ (Becker et al. 2010).

Discrete small seamounts are aligned as two chains in the east and almost parallel to the trend of MGR. The southernmost arc volcano of the Mariana volcanic front was defined to be Tracey seamount at $13^{\circ} 40^{\prime} \mathrm{N}$, just northwest of Guam, until these volcanic chains were reported by Fryer et al. (1998). They suggested that the discrete small seamounts, connecting seamounts X, C, KH98D07, and Patgon-Masala (KK00D163) (Line PAVF (presumed volcanic front) in Fig. 21.1), were a continuation of the volcanic front. Small volcanic cones on the east side of the northern half of the MGR were suggested to be formed by diffuse extension of the Mariana Trough (Alphabet Seamount Volcano Province, ASVP in Fig. 21.1, Stern et al. (2013)). Most of the seamounts in between the MGR and PAVF have conical shapes, however, two seamounts (C and PatgonMasala) have central calderas. The caldera of Patgon-Masala is called TOTO (Gamo et al. 2004). A chain of seamounts having calderas is located in the southeast of our study area (Fina Nagu Volcanic Chain (FNVC), Stern et al. (2013)). The FNVC was reported as a remnant arc volcanoes, which were active before rifting of the southern part of Mariana Trough had started (Becker 2005; Ribeiro et al. 2013b). We term the seamount chain closest to the southern part of MGR the Patgon-Masala Volcanic Chain (PMVC) (Fig. 21.1). Three small seamounts (A: Seamount A (YK92D160), KR03D01 and KR03D02) are included in the ASVP or PMVC, whereas those are categorized as off-ridge seamounts here. When the
ASVP, FNVC and PMVC are categorized in the same group hereafter, discrete seamount chains (DSC) will be used as the term indicating the locations.

Active hydrothermal venting was found in many sites along the MGR and in some places on the DSC. A white smoker $\left(>270{ }^{\circ} \mathrm{C}\right)$ was first discovered on the slope of Seamount B (Johnson et al. 1993; Gamo and The Shipboard Scientific Party of the Y9204 cruise 1993), which was named "Forecast Vent" later (Gamo et al., 1997) Then low temperature hydrothermal venting was observed at Seamounts $\mathrm{X}$ and C. An active low-temperature hydrothermal area on the MGR was discovered at $12^{\circ} 55^{\prime} \mathrm{N}$ (Snail Site) (Embley et al. 2004) and observed with Jason 2 (Fryer et al. 2003). Active black smoker venting was found at the edge of southern MGR (Archaean Site) and at one of the off-axis seamounts (KR03D01, Pika Site) (e.g., Utsumi et al. 2004; Ishibashi et al. 2004, 2006; Yoshikawa et al. 2012). In the TOTO caldera of the largest seamount, Patgon-Masala at $12^{\circ} 42^{\prime} \mathrm{N}$ (KK00D163), white and clear smoker hydrothermal activity and biological communities were found (e.g., Mitsuzawa et al. 2000; Masuda et al. 1993; Gamo et al. 2004).

\subsubsection{Sampling Locations of the Volcanic Rocks}

The studied rocks were dredged during cruises Hakuho, 1998 (KH98-1 Leg2), and Kairei, 2003 (KR03-11), sampled by using submersible, SHINKAI 6500 in 1992 (YK92-04) and 1993 (YK93-03), and ROV KAIKO in 2000 (KR00-03) (see sampling locations in Fig. 21.1). The rocks from the DSC were taken from 11 sites (ten seamounts) and those of the MGR were taken from nine locations (see Table 21.1 for locations and geologic settings).

\subsection{Analytical Methods}

In this study, the major and minor elements were measured by X-ray fluorescence photometry (XRF). Quenched glass fragments were picked from the sample surface for the analyses, however, bulk rock samples were also used for XRF analysis when not enough glass could be obtained. Water was extracted from the glass samples by thermal decrepitation in vacuo to determine water content and hydrogen isotope ratios. For the selected glass samples, concentrations of minor and rare earth elements were analyzed by induction-coupled plasma mass spectrometry (ICP-MS) and the isotopes of $\mathrm{Pb}, \mathrm{Sr}$ and $\mathrm{Nd}$ were analyzed by thermal ionization mass spectrometry (TIMS). Detailed procedures are described in the supplementary information (Analytical_Procedures). 
Table 21.1 Sampling locations of studied rocks taken from the southern Mariana Trough area

\begin{tabular}{|c|c|c|c|}
\hline Geologic settings (Segment) & Latitude & Longitude & Remarks $^{\mathrm{a}}$ \\
\hline \multicolumn{4}{|l|}{ Name $^{b}$} \\
\hline \multicolumn{4}{|l|}{ Back-arc spreading ridge } \\
\hline \multicolumn{4}{|l|}{ (Northern segment MGR) } \\
\hline KR03D08 & $13^{\circ} 12^{\prime} \mathrm{N}$ & $143^{\circ} 42^{\prime} \mathrm{E}$ & \\
\hline KH98D08 & $13^{\circ} 08^{\prime} \mathrm{N}$ & $143^{\circ} 42^{\prime} \mathrm{E}$ & \\
\hline YK99-9C & $13^{\circ} 07^{\prime} \mathrm{N}$ & $143^{\circ} 41^{\prime} \mathrm{E}$ & \\
\hline \multicolumn{4}{|l|}{ (Southern segment MGR) } \\
\hline KK00D164 & $13^{\circ} 06^{\prime} \mathrm{N}$ & $143^{\circ} 41^{\prime} \mathrm{E}$ & Aphyric obsidian. \\
\hline KR03D03 & $13^{\circ} 02^{\prime} \mathrm{N}$ & $143^{\circ} 39^{\prime} \mathrm{E}$ & \\
\hline KR03D04 & $12^{\circ} 56^{\prime} \mathrm{N}$ & $143^{\circ} 37^{\prime} \mathrm{E}$ & \\
\hline KR03D05 & $12^{\circ} 55^{\prime} \mathrm{N}$ & $143^{\circ} 35^{\prime} \mathrm{E}$ & \\
\hline KR03D07 & $12^{\circ} 45^{\prime} \mathrm{N}$ & $143^{\circ} 29^{\prime} \mathrm{E}$ & \\
\hline KR03D06 & $12^{\circ} 43^{\prime} \mathrm{N}$ & $143^{\circ} 27^{\prime} \mathrm{E}$ & \\
\hline \multicolumn{4}{|l|}{ Off-ridge axis seamount } \\
\hline \multicolumn{4}{|l|}{ (Near ASVP) } \\
\hline YK92D160 (A) & $13^{\circ} 15^{\prime} \mathrm{N}$ & $143^{\circ} 45^{\prime} \mathrm{E}$ & $\# 160-1,2$ : Ropy lava on the bottom surface of back-arc basin. \\
\hline YK92D160 (A) & $13^{\circ} 15^{\prime} \mathrm{N}$ & $143^{\circ} 45^{\prime} \mathrm{E}$ & \#160-3-8: Pillow lava from the slope of the seamount. \\
\hline \multicolumn{4}{|l|}{ (Near PMVC) } \\
\hline KR03D01 & $12^{\circ} 55^{\prime} \mathrm{N}$ & $143^{\circ} 38^{\prime} \mathrm{E}$ & \\
\hline KR03D02 & $12^{\circ} 54^{\prime} \mathrm{N}$ & $143^{\circ} 38^{\prime} \mathrm{E}$ & Aphyric obsidian. \\
\hline \multicolumn{4}{|l|}{ Discrete chain seamounts } \\
\hline \multicolumn{4}{|l|}{ (Northern segment) } \\
\hline \multicolumn{4}{|l|}{ (Western chain ASVP) } \\
\hline YK93D189 (C) & $13^{\circ} 08^{\prime} \mathrm{N}$ & $143^{\circ} 45^{\prime} \mathrm{E}$ & \#189-1-3: Pillow lava on the slope of the seamount \\
\hline YK93D189 (C) & $13^{\circ} 08^{\prime} \mathrm{N}$ & $143^{\circ} 50^{\prime} \mathrm{E}$ & \#189-5,6: No quenched glass and bulk rock was analyzed. \\
\hline \multicolumn{4}{|l|}{ (Eastern chain ASVP) } \\
\hline YK92D161 (B) & $13^{\circ} 25^{\prime} \mathrm{N}$ & $143^{\circ} 55^{\prime} \mathrm{E}$ & \\
\hline YK93D186 (X) & $13^{\circ} 15^{\prime} \mathrm{N}$ & $144^{\circ} 01^{\prime} \mathrm{E}$ & \\
\hline \multicolumn{4}{|l|}{ (Sothern seamounts) } \\
\hline \multicolumn{4}{|l|}{ (PMVC) } \\
\hline KK00D163 & $12^{\circ} 42^{\prime} \mathrm{N}$ & $143^{\circ} 32^{\prime} \mathrm{E}$ & Bulk rock was analyzed. \\
\hline \multicolumn{4}{|l|}{ (Patgon-Masala) } \\
\hline KH98D07 & $12^{\circ} 58^{\prime} \mathrm{N}$ & $143^{\circ} 44^{\prime} \mathrm{E}$ & \\
\hline KH98D05 & $12^{\circ} 33^{\prime} \mathrm{N}$ & $143^{\circ} 25^{\prime} \mathrm{E}$ & \\
\hline \multicolumn{4}{|l|}{ (FNVC) } \\
\hline KH98D06 & $12^{\circ} 51^{\prime} \mathrm{N}$ & $143^{\circ} 50^{\prime} \mathrm{E}$ & Titanomagnetite including zenolith was recovered with basalt \\
\hline
\end{tabular}

${ }^{a}$ Quenched glass rim fragments were used for the analyses except where noted in remarks

${ }^{\mathrm{b}}$ The name is the same as those shown in Fig. 21.1

Words in parentheses are the names of seamounts, which are used in the text instead of the site name

\subsection{Results}

\subsubsection{Rock Observations}

The rock samples studied are mostly basalt to andesite. Quenched glasses were recovered from most of the sampling sites. However, the rocks without quenched glass rims were obtained from inside the calderas at Seamount $\mathrm{C}$ (YK98D189 4-6), site KH98D06 (no name) and TOTO caldera (KK00D163). Aphyric glass was recovered from only two sites, at the center of the MGR (KK00D164) and at one of the off-axis seamounts (KR03D02). The dredged rocks from the latter site were dacitic obsidian.

Plagioclase and minor olivine phenocrysts are common in all of the rocks from the MGR. In addition to plagioclase and olivine, pyroxene occasionally forms phenocrysts in the rocks from the ASVP and PMVC; e.g., orthopyroxene was observed in rocks from Seamounts A and B (Yamatani et al., 1994), and those from the TOTO caldera, and clinopyroxene was observed in those from Seamount B (Yamatani et al. 1994). A gabbroic xenolith including a large amount of titanomagnetite was recovered in basalt from the bottom of the caldera at site KH98D07 (Fig. 21.1). 


\subsubsection{Major Element Chemical Composition}

Analytical results of major and minor element compositions, water contents and $\delta^{2} \mathrm{H}$ values are shown in supplementary data (Table 21-S-1). The rock chemistries of DSC are categorized into six groups corresponding to the location of the seamounts as noted above, thus those will be described according to this category; northern segment is abbreviated ASVP, according to the name "Alphabet Seamount Volcanic Chain (Stern et al. 2013), and the sampling sites are subgrouped as off-ridge axis seamount (ASVP-OR), western seamounts (ASVP-W), and eastern seamounts (ASVP-E); southern segment is divided into two areas, PMVC and FNVC, and the PMVC is sub-divided into off-ridge axis seamounts (PMVC-OR) and western ridge (PMVC-W) (Figs. 21.1, 21.2, 21.3, 21.4, 21.5, 21.6, 21.7, and 21.8).

AFM composition of DSC rocks follows the tholeiite series, subparallel to the MORB trend, while most of the rocks from the MGR fall in the calk-alkaline field between tholeiite series rocks and the so-called "extreme backarc basin rocks" (XBABB) from the Manus Basin (Sinton et al. 2003) (Fig. 21.2). Relationships of major components to $\mathrm{SiO}_{2}$ show two trends (Fig. 21.3). $\mathrm{SiO}_{2}$ content of MGR rocks ranges from 53 to $63 \%$, whereas that of DSC rocks, except off-ridge axis seamounts (ASVP-OR and PMVC$\mathrm{OR}$ ), ranges from 51 to $56 \%$. Except for a few samples, the rocks from the MGR and those from the DSC comprise the two different trends of chemical variation relative to $\mathrm{SiO}_{2}$ concentration. The rocks from the MGR generally

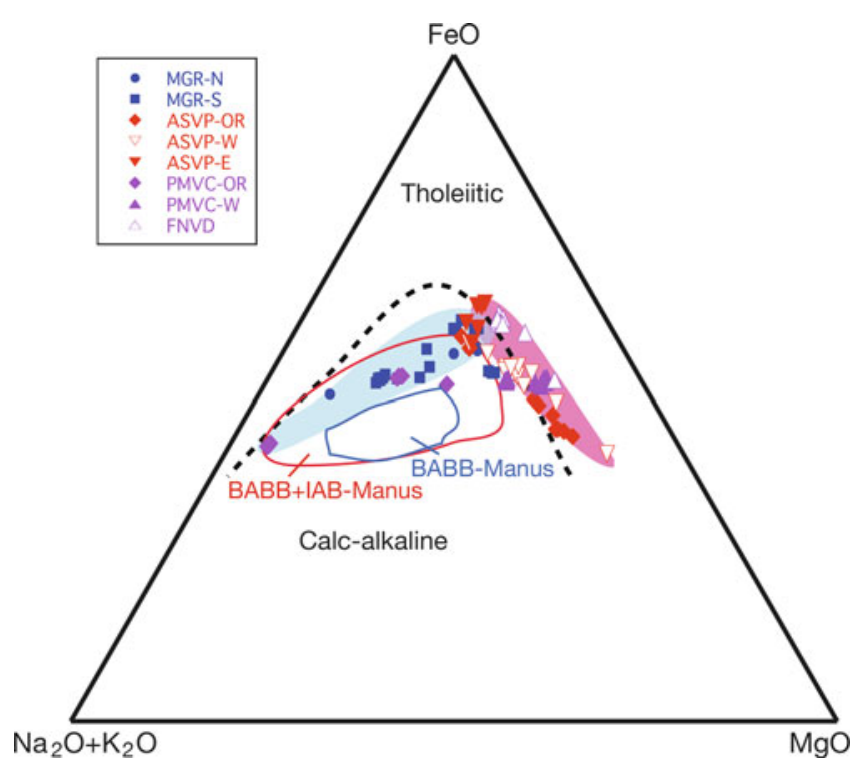

Fig. 21.2 AFM diagram of the submarine volcanic rocks from the southern Mariana Trough area. The boundary between tholeiitic and calc-alkaline rocks (dashed line) is after Irvine and Baragar (1971). Symbols indicate the sampling locations as in Fig. 21.1. The areas colored pink and blue are the fields of tholeiite series and BABB rocks show a roughly linear relationship with increasing $\mathrm{SiO}_{2}$; e.g., $\mathrm{Mg} \#(\mathrm{Mg} /(\mathrm{Mg}+\mathrm{Fe}))$ decreases and $\mathrm{Na}_{2} \mathrm{O}+\mathrm{K}_{2} \mathrm{O}$ increases with increasing $\mathrm{SiO}_{2}$. Those linear correlations suggest fractional differentiation of the magma formed from the same source. Sinton et al. (2003) showed that essentially no enrichment of $\mathrm{Fe}$ occurred during progressive differentiation of the Manus Basin XBABB. The Fe concentration of rocks from the MGR show a clear negative trend with increasing silica content, suggesting similar controls over differentiation in our study area. Because the total $\mathrm{Fe}$ and $\mathrm{CaO}$ contents decrease with increasing $\mathrm{SiO}_{2}$, olivine and anorthite crystallization-precipitation is the main factor affecting major element chemistry.

$\mathrm{SiO}_{2}$ content of the rocks from ASVP-OR and PMVC-OR has a much broader range, from $49 \%$ (Seamount A) to $68 \%$ (dacitic obsidian from KR03D02), and some of those lie on the trend of those from the MGR. The rocks from the base of Seamount A (D\#160-1-2, very close to the northern segment of the MGR) represent an end-member of the MGR composition, whereas the rocks from the upper flanks of this seamount are included in the field of the DSC rocks. Also, the plots of some rocks from MGR, such as KR03D06, give obvious similarity to those of DSC rocks, i.e., they have lower $\mathrm{Na}_{2} \mathrm{O}+\mathrm{K}_{2} \mathrm{O}$ and $\mathrm{TiO}_{2}$ contents. The intersection of the MGR and DSC magmas indicates two types of magmatic processes occur in the same place.

\subsubsection{Minor Element Composition}

Among the minor elements analyzed here, the relationships between $\mathrm{Ti}$ and $\mathrm{V}$ and $\mathrm{La} / \mathrm{Yb}$ and $\mathrm{Ba} / \mathrm{La}$ characterize two types of magmas in the studied area. The relationship between $\mathrm{Ti}$ and $\mathrm{V}$ (Fig. 21.4, concentrations are in Table 21.S-1) indicates the redox condition of mantle source regions for magmas and thus for tectonic settings (Shervais 1982). The Ti and $\mathrm{V}$ ratios of most of the rocks from the MGR are $>20$, and thus fall in the fields of backarc basin basalt (BABB), mid-ocean ridge basalt (MORB), and ocean island basalt (OIB). Those that fall in the latter area are highly differentiated MGR rocks. Most samples with $\mathrm{SiO}_{2}$ content $<55 \%$, including the lavas from the base of Seamount $\mathrm{A}$, fall between Ti/V ratio of 25 and 30 . The highly differentiated samples, including those from the TOTO caldera, have much higher ratios, which would reflect precipitation of minerals during differentiation, not the mantle source redox conditions.

$\mathrm{Ti} / \mathrm{V}$ ratios of the DSC rock are generally $<20$, indicating the arc nature of these lavas. It is notable that the ranges of $\mathrm{Ti} / \mathrm{V}$ ratio can be separated into two areas corresponding to the locations of seamounts; i.e., the rocks from the seamounts north from $13^{\circ} \mathrm{N}$ (ASVP-W and E) have Ti/V ratios between 18 and 22, and those from south (PMVC-W 


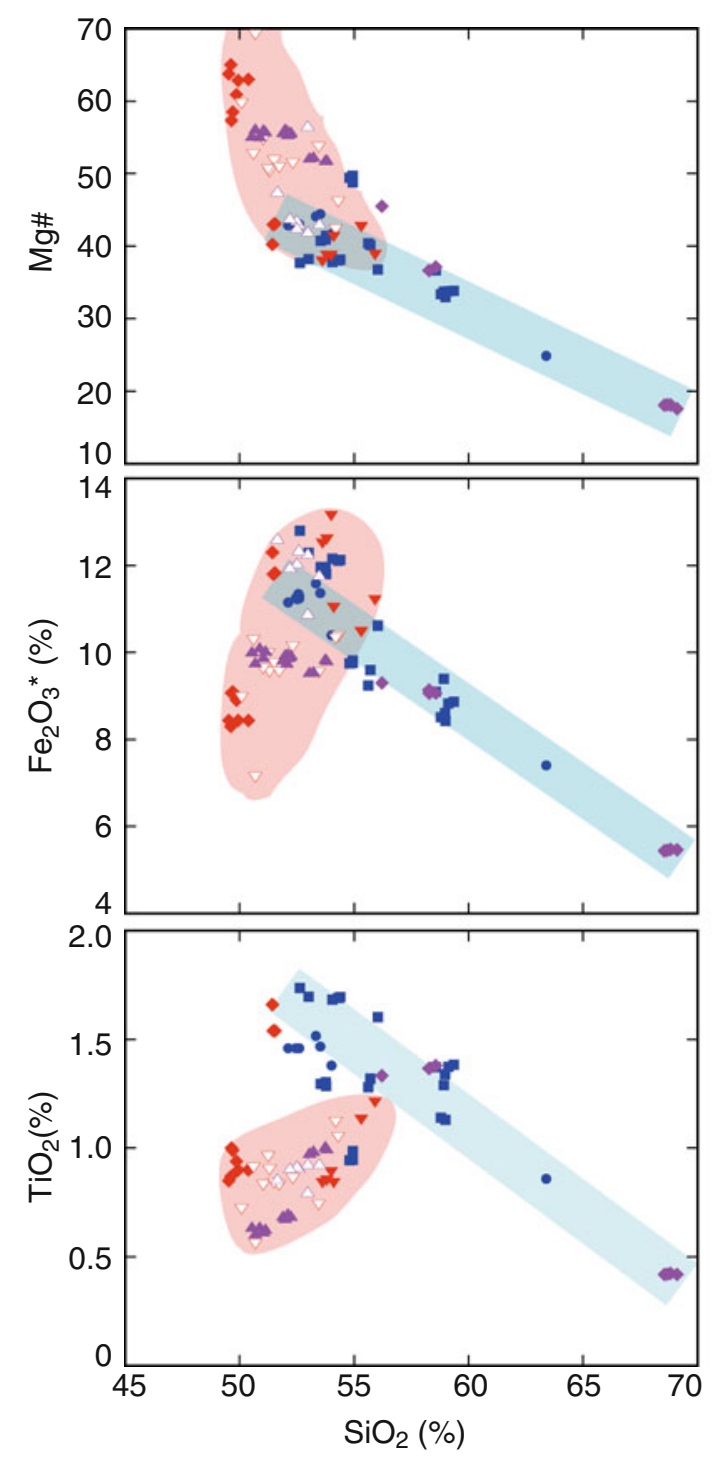

Fig. 21.3 Major element chemistry and water content vs. $\mathrm{SiO}_{2} \%$ of the submarine volcanic rocks from the southern Mariana Trough. The boundary between alkaline and subalkaline rocks (dashed line) in the $\mathrm{SiO}_{2}$ vs. $\mathrm{Na}_{2} \mathrm{O}+\mathrm{K}_{2} \mathrm{O}$ is after Macdonald (1968). Symbols indicate the

and FNVC) are between 13 and 15. The rocks from two sites on the MGR (KR03-D06 and D03) also fall within the same area as those from the ASVP. The values of rocks from PMVC-W and FNVC are almost the same as those of Tracey Seamount, the southernmost large arc volcano (Stern et al. 2013). Thus, the source magma of the rocks from the DSC, especially those from the southern DSC, is arc-like rather than BABB-like, based on this figure.

$\mathrm{Ba} / \mathrm{La}$ vs. ( $\mathrm{La} / \mathrm{Yb}$ )n (Fig. 21.5) is widely used as an indicator of aqueous fluid contribution from source magmas (e.g., McCulloch and Gamble 1991; Hawkesworth et al. 1993). The most primitive rocks of the study area, which have the lowest $\mathrm{SiO}_{2}$ concentrations, are from the MGR and have the ranges of $\mathrm{Ba} / \mathrm{La}$ vs. $(\mathrm{La} / \mathrm{Yb}) \mathrm{n}$ ratios closest to that

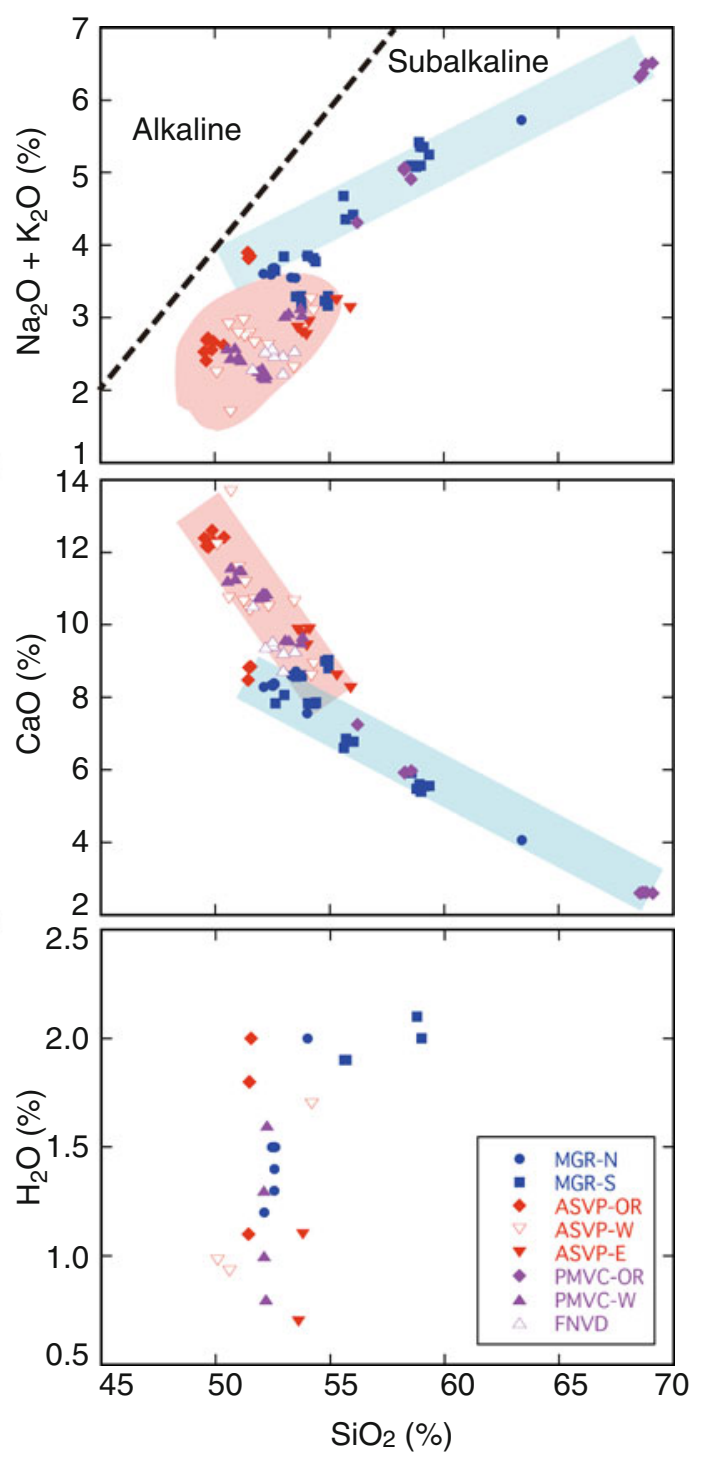

sampling locations as in Fig. 21.1. Blue line shows differentiated compositions of studied rocks mainly sampled from the MGR. The field colored pink gives the range of the other group of rocks, probably derived by mixing of n-MORB and depleted mantle source magmas

of MORB. It is notable that one of the end-members of the DSC rocks is almost the same as the most primitive rocks of the MGR. The $\mathrm{Ba} / \mathrm{La}$ and $(\mathrm{La} / \mathrm{Yb}) n$ ratios of DSC rocks vary in two different trends from the above end-member. Ba concentration of the rocks from ASVP-W and E lie at nearly constant $(\mathrm{La} / \mathrm{Yb}) n$ values toward the end-member of metazomatized mantle, whereas the rocks from PMVC and FNVC lie at nearly constant $\mathrm{Ba} / \mathrm{La}$ values.

Minor element compositions including rare earth elements (REE) of selected samples after normalizing with normal MORB (n-MORB) are given in Table 21.S-2 and shown in Fig. 21.6. Among the minor elements, $\mathrm{Rb}, \mathrm{Ba}$, Th, $\mathrm{U}, \mathrm{Pb}$, and $\mathrm{Sr}$ are enriched and $\mathrm{Nb}$ is depleted in the studied rocks, indicating that the elements derived from lithosphere 
Fig. 21.4 Relationship between

$\mathrm{Ti}$ and $\mathrm{V}$ concentrations of submarine volcanic rocks from the southern Mariana Trough. Tectonic settings designations after Shervais (1982). Heavy lines of $\mathrm{Ti} / \mathrm{V}$ ratios distinguish the fields of arc lava $(\mathrm{Ti} / \mathrm{V}<20)$, backarc-basin basalt (BABB) and mid-ocean ridge basalt (MORB) $(20<\mathrm{Ti} / \mathrm{V}<50)$, vs. ocean island basalt $(\mathrm{OIB})(\mathrm{Ti} / \mathrm{V}>50)$. Symbols indicate the sampling locations as in Fig. 21.1
Fig. 21.5 Relationship between $\mathrm{Ba} / \mathrm{La}$ and $(\mathrm{La} / \mathrm{Nd}) \mathrm{n}$. The graph is modified after Lin et al. (1989). Symbols indicate the sampling locations as in Fig. 21.1
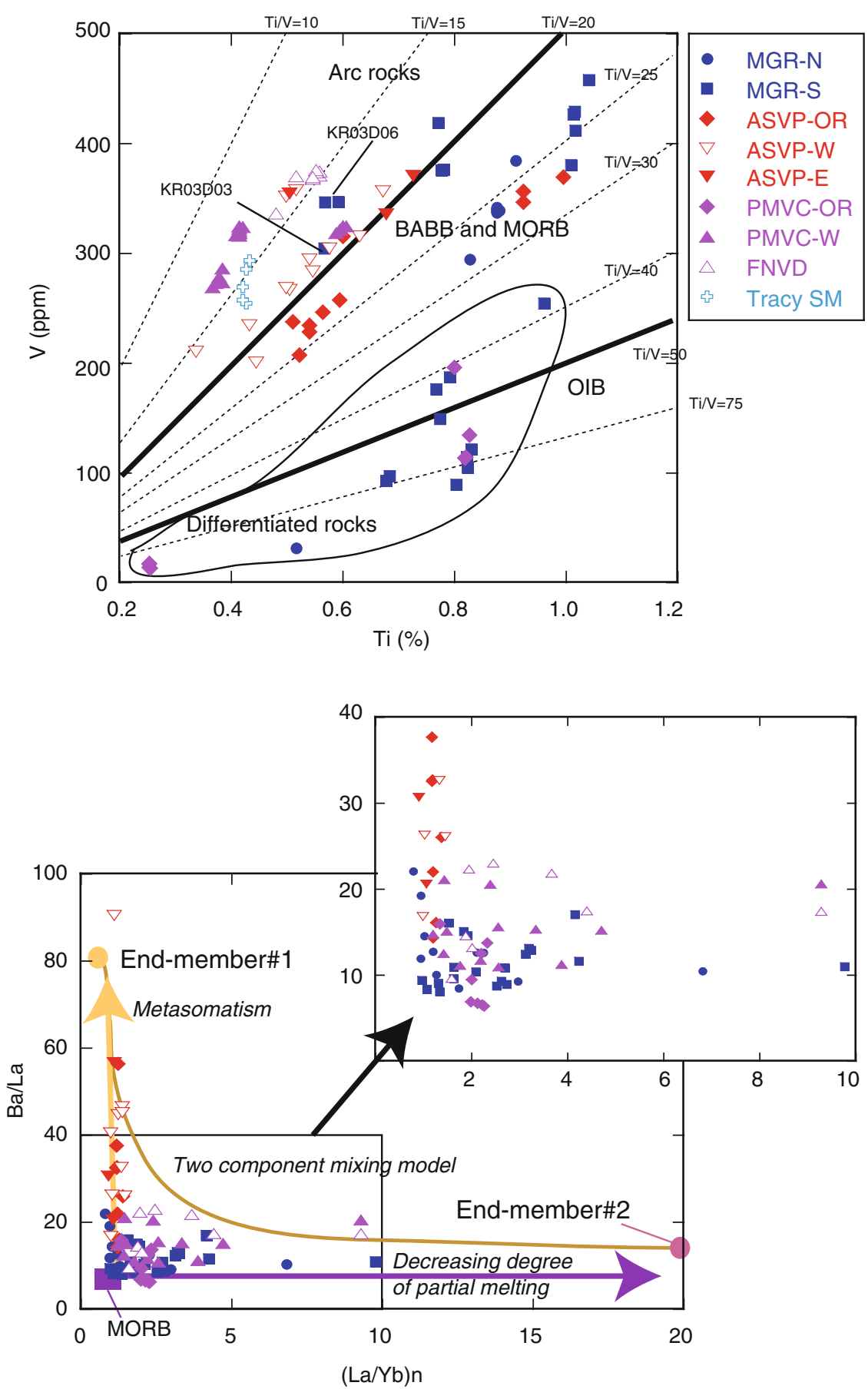

or subduction components are more dominant in the DSC than the MGR. The concentration of Ta from the DSC is extremely high compared with reported rocks from the whole Mariana area. Ta is concentrated in the mantle and behaves in accordance with $\mathrm{Nb}$ (Pearce et al. 2005). The normalized concentrations of $\mathrm{Nb}$ and $\mathrm{Ta}$ of MGR rocks are similar to those of Mariana Trough backarc basin rocks summarized by Pearce et al. (2005), although we cannot explain the enrichment of $\mathrm{Ta}$ at present.

\subsubsection{Rare Earth Element Compositions}

REE compositions normalized to n-MORB are shown in Table 21-S-2 (Supplementary information) and Fig. 21.7. Most of the analyzed rocks from the MGR and DSC have REE patterns similar to that of n-MORB. A rock from the base of Seamount A, which has one of the lowest $\mathrm{SiO}_{2}$ concentration (51.4\%, Table 21.S-1) among the studied rocks, also shows a pattern similar to that of n-MORB. The 


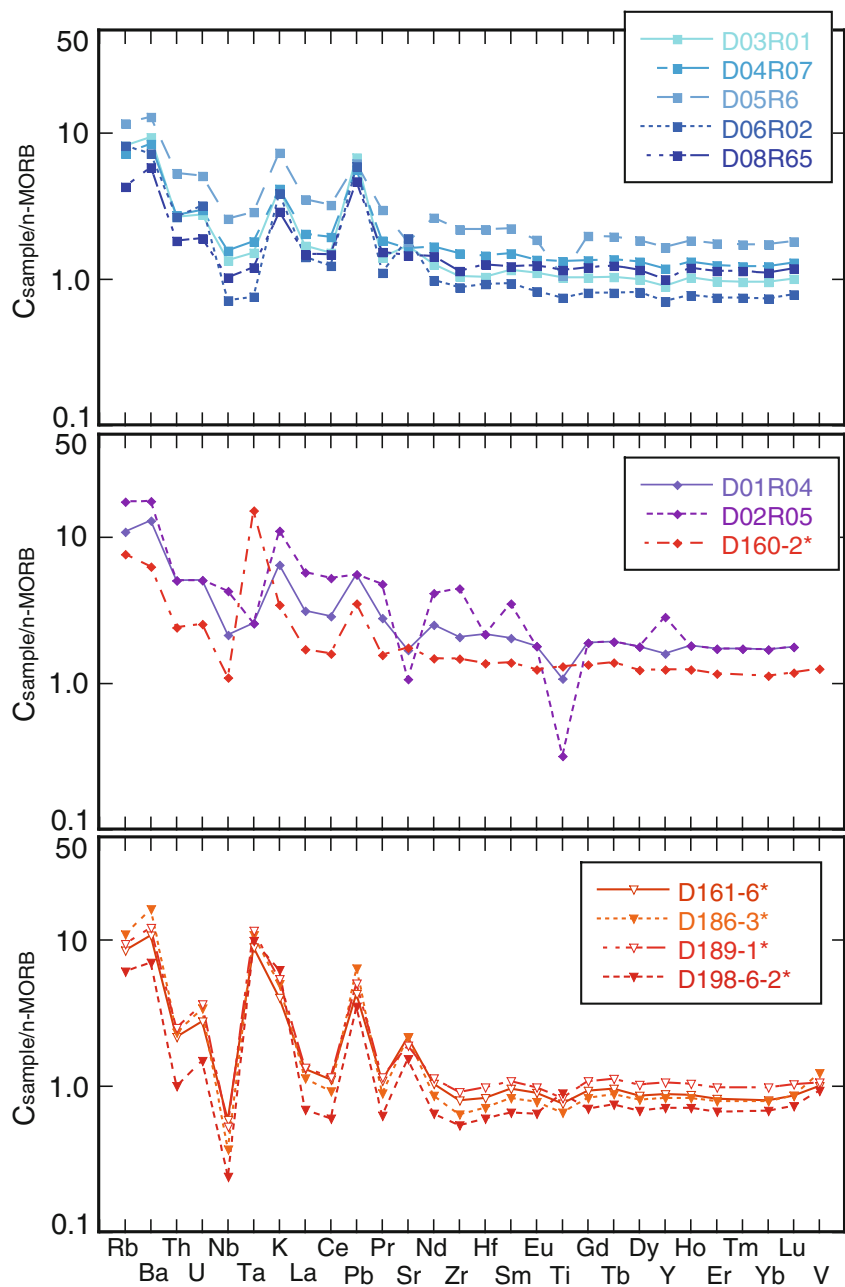

Fig. 21.6 Minor and rare earth element chemistry of selected submarine volcanic rocks from the southern Mariana Trough. The concentrations are normalized to n-MORB (Sun and McDonough (1989) and Sun et al. (1979). The sample name with an asterisk shows that the data used was from Stern et al. (2013)

MGR rocks are enriched in LREEs between La and Sm, probably in association with progressive differentiation. There is a slight depletion in LREEs among some of the ASVP rocks (D161-6*, D186-3* and D189-1* in Fig. 21.7). It is notable that a small $\mathrm{Ce}$ depletion occurs in all the samples. The minor elements and REE patterns of the rocks studied indicate that one of the end-member magmas originated from a source similar to that of the MGR and DSC, yet the processes responsible for the chemical characteristics are different in each area.

\subsection{5 $\mathrm{Pb}, \mathrm{Sr}$ and $\mathrm{Nd}$ Isotopes}

Analytical results of $\mathrm{Pb}, \mathrm{Sr}$ and $\mathrm{Nd}$ isotope are in Table 21-S-3 (Supplementary information) and those systematics are shown in Fig. 21.8. Plots of $\mathrm{Pb}$ isotopes lie close to the

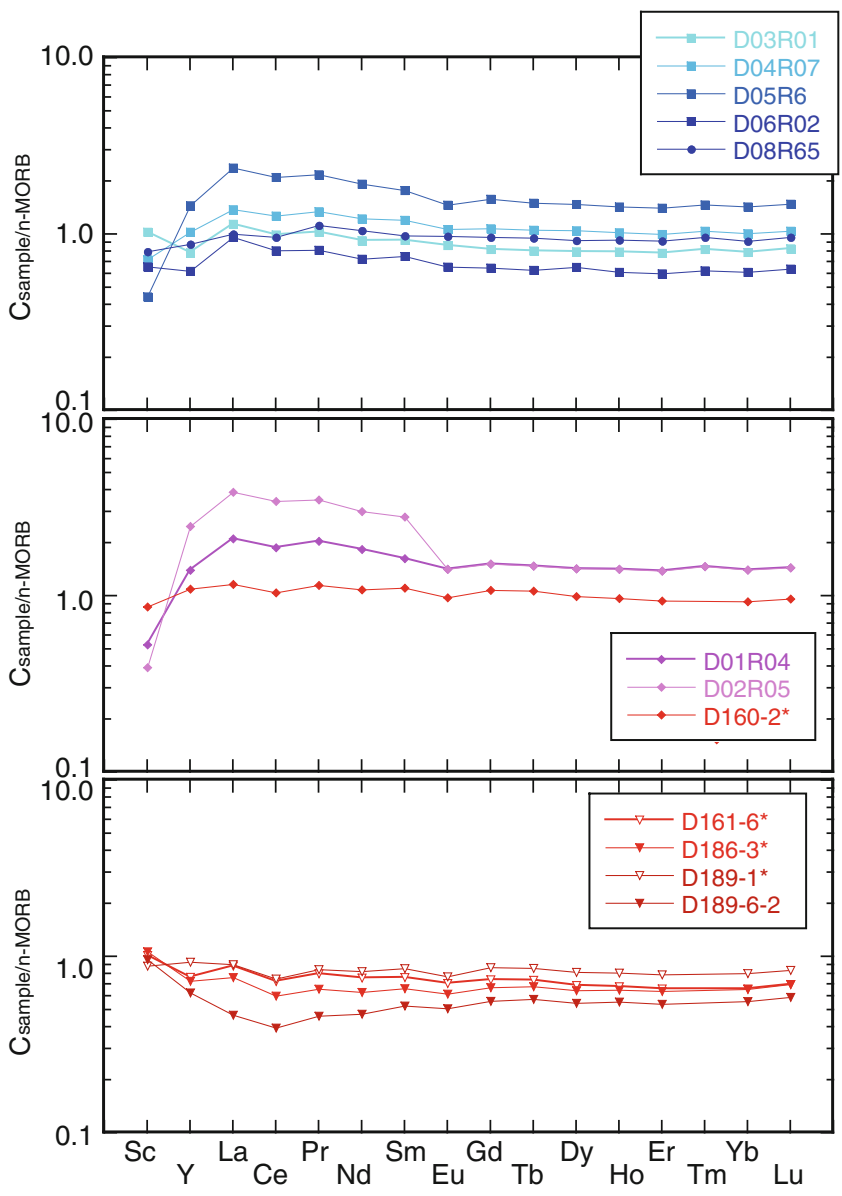

Fig. 21.7 Rare Earth element chemistry of selected submarine volcanic rocks from the southern Mariana Trough. The concentrations are normalized to MORB values published by Sun and McDonough (1989). The sample name with an asterisk shows that the data used was from Stern et al. (2013)

Northern Hemisphere Regression Line (NHRL in Fig. 21.8) (Hart 1984) and the rocks from MGR except for one (KR03D06R02), which has a composition similar to that of DSC rocks as described above, are in the ranges of spreading ridge volcanic rocks reported for the central graben of the northern (Gribble et al. 1998), middle (at $18^{\circ} \mathrm{N}$ ), and southern Mariana Trough (at $14^{\circ} \mathrm{N}$ ) (Volpe et al. 1990; Gribble et al. 1996). Thus, the MGR rocks are derived from a source similar to that of Mariana Trough basalts from farther north.

The relationship between ${ }^{87} \mathrm{Sr} /{ }^{86} \mathrm{Sr}$ and $\varepsilon \mathrm{Nd}$ indicates the trends of two different sources of magmas for the study area more clearly (Fig. 21.8). MGR rocks have a linear negative correlation. The distribution of MGR data points lie in the field of previously reported BABB from the southern and middle Mariana Trough. Most of the DSC rocks have positive correlation. In the figure, end-member \#1 is depleted magma (or melt therefrom) with a source similar to MORB that has been metazomatized, and end-member \#2 (or melt therefrom) is an LIL- and LREE-enriched OIB-like source 

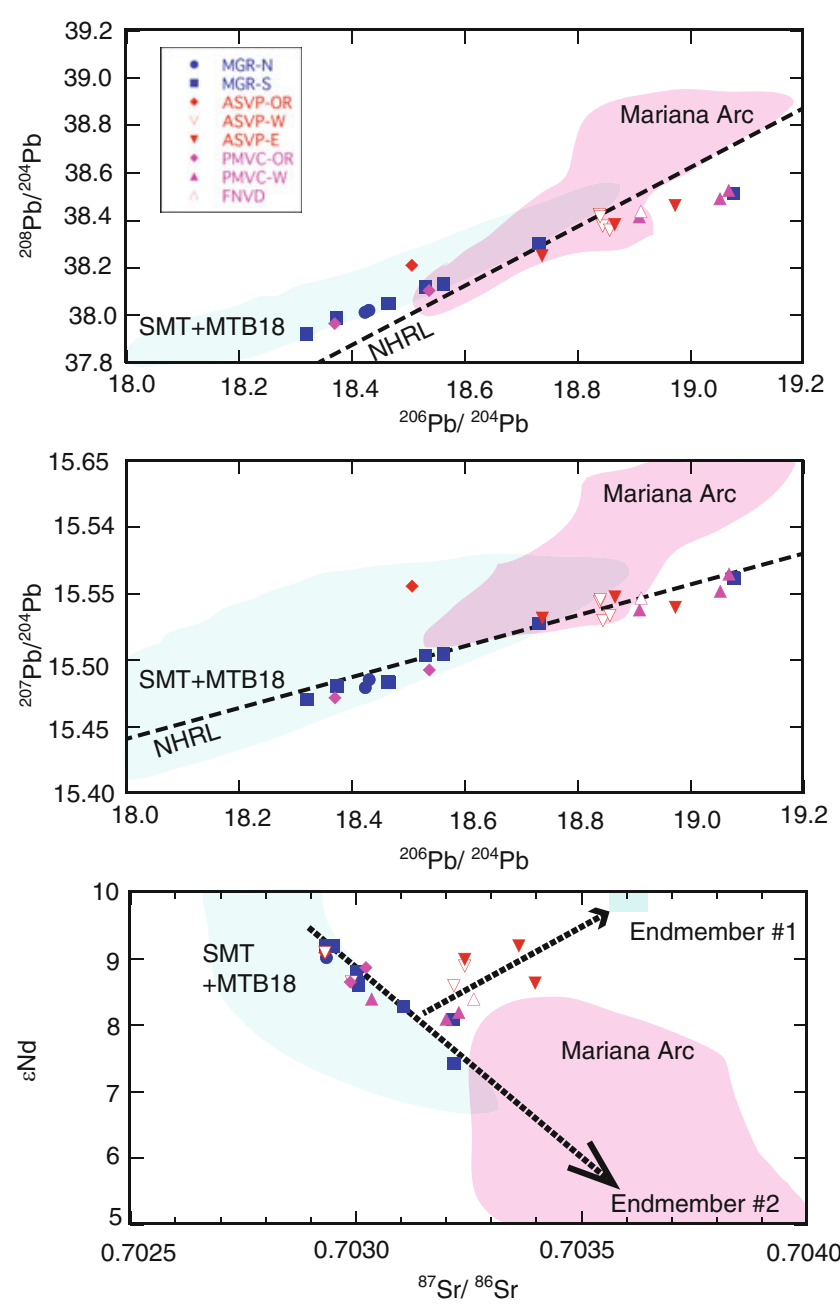

Fig. 21.8 Relationships among $\mathrm{Pb}$ isotopes and between $\mathrm{Sr}$ and $\mathrm{Nd}$ isotopes. The NHRL is Northern Hemisphere Regression Line of Hart (1984). The fields for spreading ridge segments, NMT, SMT, MTB-18 are from Gribble et al. (1998), Volpe et al. (1990) and Gribble et al. (1996). The Mariana arc data are from Gribble et al. (1998) and Stern et al. (1993). End-members \#1 and \#2 are depleted mantle and OIB (Lin et al. 1989) respectively. Symbols indicate the sampling locations as in Fig. 21.1

(Lin et al. 1989). For the rocks studied, the latter would be unlikely. DSC rocks including one from FNVC plausibly are affected by a metazomatized MORB source, as indicated by Ba enrichment noted above. The difference in compositions of rocks from the MGR vs. the DSC is attributed to the compositions of source magma.

\subsubsection{Water and Hydrogen Isotope Ratios}

Although we have limited data regarding water content and hydrogen isotope ratios for the glasses studied (Table 21-S-1 in Supplementary information), it is possible to make preliminary observations. The water content may show a slight positive correlation with $\mathrm{SiO}_{2}$ content, especially those from MGR rocks (Fig. 21.3). However, the water content is not related to sampling depth, and is not a simple function of degassing. All five samples that show $\sim 2 \% \mathrm{H}_{2} \mathrm{O}$ are from the area of the intersection between the northern and southern MGR. This is also the area in which a magma chamber reflector was resolved on 6-channel seismic reflection data (Becker et al. 2010). Becker et al. (2010) suggested the high $\mathrm{R}$ value (contrast in acoustic impedance) of the magma chamber reflector is consistent with a high gas content in the magma chamber.

The hydrogen isotope ratios $\left(\delta^{2} \mathrm{H} \%\right.$, VSMOW) are higher in the MGR rocks ( -36 to $-45 \%$ ) than in the rocks from the DSC ( -45 to $-55 \%$ ). The hydrogen isotope ratios of the MGR rocks are comparable to those reported by Poreda (1985), i.e., values between -32 and $-47 \%$ for the Mariana Trough basalts from $18^{\circ}$ to $16^{\circ} \mathrm{N}$, which are larger than commonly known values of MORB $(-80 \pm 5 \%$, Kyser and O'Neil 1984) and those of deepseated mantle ( -80 to $-60 \%$, Boettcher and O'Neil 1980).

\subsection{Discussion}

The early studies of petrology suggested that the Mariana Trough basalts originated from melts of a primitive mantle that was enriched in volatiles, alkalis, alkaline earths, and LREE relative to $n-M O R B$ because of metasomatic modification of the source mantle (Fryer et al. 1981; Hawkins and Melchior 1985; Sinton and Fryer 1987). Sinton and Fryer (1987) interpreted the enrichment of $\mathrm{Ba}>\mathrm{Rb}>\mathrm{K}>$ LREE $>\mathrm{Sr}$ and depletion in $\mathrm{Y}$ in the Mariana Trough source to reflect the addition of a depleted suprasubduction-zone mantle component primarily derived by low-degree of melting of the descending eclogitic slab. Based on $\mathrm{Sr}-\mathrm{Nd}-\mathrm{Pb}$ isotope data, magma mixing of depleted MORB source mantle and arc-like lithospheric components were presumed to form heterogenous Mariana backarc basin magmas at about $18^{\circ} \mathrm{N}$ (Volpe et al. 1987, 1990), whereas the southern Mariana backarc basin basalts have MORB-like compositions modified by a slab-derived fluid (Gribble et al. 1996; Macpherson et al. 2000; Taylor and Martinez 2003). Here, two source magmas and those mixing are obvious; n-MORB type mantle and depleted mantle formed via metasomatism of n-MORB type mantle. In the DVC rocks, occasionally $\mathrm{Ba}$ is enriched but not $\mathrm{Th}$ or $\mathrm{Nb}$, suggesting that the metazomatized fluid would be derived from the shallower part of descending slab (e. g., Pearce et al. 2005). However, contamination of the source by crustal components including melt of oceanic crust and fluids from the descending slab were not obvious in the MGR rocks, since the $\mathrm{Pb}, \mathrm{Sr}$ and $\mathrm{Nd}$ isotopes do not give any contribution from the metazomatized fluids in those rocks. Enrichment of LREE 
in the MGR and off-ridge axis seamounts was likely caused by differentiation or by a low degree of partial melting of n-MORB-type mantle.

The relationship between Ti and V indicates that the DSC magmas had two different redox conditions, both of which lie within the range of arc lavas (Fig. 21.4). Solubility of V in silicate melts is dependent on the redox state of $\mathrm{V}\left(\mathrm{V}^{3+} / \mathrm{V}^{4+}\right)$. Because $\mathrm{V}^{3+}$ decreases with increasing $\mathrm{fO}_{2}($ Canil 1999) and $\mathrm{V}^{4+}$ tends to behave as an incompatible element, higher $\mathrm{V}$ contents relative to $\mathrm{Ti}$ reflect more oxidizing conditions. If this is applicable to our study area, the source magmas in the southern segment of DSC (PMVC and FNVC) are more oxidizing than those in the northern ones (ASVP). As a controlling factor for redox conditions of the magmas formed in the suprasubduction-zone mantle wedge, silicate melt is considered to be a more effective oxidizer than solute-rich hydrous fluid (Parkinson and Arculus 1999). Although the DSC rocks are apparently not affected by subduction components, the more oxidizing condition of the southern than northern DSC magmas, which were more affected by the metazomatizm.

Lower V content in the MGR rocks are in the ranges for backarc basin basalts (Shervais 1982) indicating a more reducing condition in the source magma than in arc magmas. Some of the rocks from the MGR (KR03-R06, KR03-R03) are indistinguishable from the southern DSC (DMVC-W and FNVC) rocks. This would mean that both MGR and DSC magmas have similar source magmas, especially in the southern segments where they merge spatially.

Pearce et al. (2005) explained the complexities of mixing of subduction mobile elements in the mantle sources for Mariana arc lavas, lavas formed during backarc rifting, and the back arc spreading center lavas by plotting deviations from a MORB array, which was defined for the Mariana/ Philippine-Sea regions. They used comparison of ratios of various subduction mobile to immobile elements as proxies for total subduction addition. For example, $\mathrm{Ba} / \mathrm{Yb}$ and $\mathrm{Th} /$ $\mathrm{Yb}$ vs. $\mathrm{Ta} / \mathrm{Yb}$ plots are used for detecting the addition of subduction components. The ranges of these ratios for our studied rocks from the MGR are $\mathrm{Ba} / \mathrm{Yb}(1.3-2.3), \mathrm{Th} / \mathrm{Yb}$ (0.06-0.14), and $\mathrm{Ta} / \mathrm{Yb}(0.04-0.07)$, indicating pure mantle source of southern Mariana Trough basalts. The rocks from ASVP give slightly higher $\mathrm{Ba} / \mathrm{Yb}$ (1.1-4.3), but almost the same $\mathrm{Th} / \mathrm{Yb}(0.06-0.12)$. None of the samples we report lie within the field of arc lavas from Pearce et al. (2005) with regard to these trace element ratio considerations. This is consistent with the low $\mathrm{Ba} / \mathrm{La}$ ranges (from 7 to 14 ) for the MGR and 20.5 to 36.2 for the DSC indicating relatively low slab-fluid contribution to the MGR, consistent with the systematics of $\mathrm{Pb}, \mathrm{Sr}$ and $\mathrm{Nd}$ isotopes as noted above.

Based on Nd and Sr isotope systematics, Lin et al. (1989) proposed that the Mariana island arc lavas represent the mixing of three end-member components; hydrous fluid derived from the subducted sediments, OIB-type mantle and MORB. Lin et al. (1989) explained that the Mariana arc magma was derived from a depleted MORB-like mantle that has been recharged with $\mathrm{K}, \mathrm{Rb}, \mathrm{Sr}$ and $\mathrm{Ba}$ by hydrous fluids. Our data of $\mathrm{Pb}, \mathrm{Sr}$, and $\mathrm{Nd}$ isotopes indicate that the DSC rocks occasionally contained small amount of components derived from metazomatized fluid (Fig. 21.8), probably derived from the shallower part of descending slab. However, unlike the Mariana arc lavas, those rocks would not contain component derived from melted oceanic crust. The FNVC was termed a remnant arc, which was active before opening of the Trough in this area ( $\sim 3 \mathrm{Ma}$ ) (Ribeiro et al. 2013a). However, the $\mathrm{Pb}, \mathrm{Sr}$, and $\mathrm{Nd}$ isotope systematics do not show any difference from the other rocks of the DSC.

Sources of the water in the samples studied are presumed to be in the mantle wedge, seawater, or they could also have been affected by replenishment from other sources along strike or by mantle-wedge corner flow, but fluids directly from hydrous minerals in the subducting slab are likely minimal in our samples based on $\delta^{2} \mathrm{H}$ values. The Mariana Trough rocks are reported to have higher volatile content, including $\mathrm{H}_{2} \mathrm{O}$, than n-MORB (e.g., Garcia et al. 1979; Stolper and Newman 1992, 1994). The studied rocks from the MGR contained higher amounts of $\mathrm{H}_{2} \mathrm{O}(1.2-2.2 \%)$ than n-MORB $(<0.5 \%)$. Higher $\mathrm{H}_{2} \mathrm{O}$ content of the BABB than that of the adjacent arc volcanic rocks has been thought to be essential for producing backarc basin magma (e.g., Garcia et al. 1979), because the higher water content acted to lower the melting temperature in the wedge mantle. A small amount of $\mathrm{H}_{2} \mathrm{O}$ lowers the melt liquidus temperature and suppresses plagioclase crystallization relative to olivine and clinopyroxene (Fryer et al. 1981; Danyushevsky 2001; Taylor and Martinez 2003). Also, in general, the $\mathrm{H}_{2} \mathrm{O}$ content increases with progressive differentiation evidenced by decreasing $\mathrm{MgO}$ and increasing $\mathrm{Al}_{2} \mathrm{O}_{3}$ and $\mathrm{FeO} *$ (Danyushevsky 2001), especially at lower temperature; e. g., a larger amount of $\mathrm{H}_{2} \mathrm{O}$ than $3 \%$ in the melt causes enrichment in $\mathrm{SiO}_{2}$ and depletion in $\mathrm{MgO}$ at $1,100{ }^{\circ} \mathrm{C}$ compared with anhydrous melts (Hirose and Kawamoto 1995). Weakly negative correlation of $\mathrm{H}_{2} \mathrm{O}$ content may be present to $\mathrm{Mg \#}$ and $\mathrm{TiO}_{2}$ concentration, although it is not clear whether differentiation or partial melting is related to the $\mathrm{H}_{2} \mathrm{O}$ content of the source magmas of this area. Kyser and O'Neil (1984) noted that the direct addition of seawater into tholeiite magmas increased water content and hydrogen isotope ratios. They found that Mid-Atlantic Ridge basalts gave a maximum $\delta^{2} \mathrm{H}$ value of $-35 \%$ with seawater infusion into the source magma. Seawater injection into magma is a plausible mechanism in and around ocean crust, e.g., the heavy hydrogen isotope ratios of granitic rocks at Ascension Island were explained by seawater infusion into the magma (Sheppard and Harris 1985). Seawater infusion into the 
MGR magma may explain the heavier $\delta^{2} \mathrm{H}$ values than those of MORB and rocks from the DSC. Slightly negative anomalies of $\mathrm{Ce}$ would be another evidence of seawater injection into the magma. The widespread faulting associated with a high degree of deformation of the southeastern part of the Mariana forearc (southeast of the DSC) in the study area (Fryer et al. 2003) would provide avenues for intrusion of seawater into the lithosphere of this part of the basin far more readily than elsewhere in the Mariana backarc setting.

Taylor and Martinez (2003) indicated that hydrous fluxing enhances decompression melting of depleted mantle sources just behind the island arc and produces spreading axes with "fast-spreading" morphology. They also suggested that the increasing $\mathrm{H}_{2} \mathrm{O}$ and $\mathrm{Ba} / \mathrm{La}$ ratio were evidence of relationship of slab-derived water affecting backarc magma production in other parts of the Mariana Trough. Based on the U-series isotope characteristics of the rocks in the Valu Fa ridge, a similar mantle chemistry was presumed beneath the arc and backarc spreading areas in the Lau Basin, whereas slab-derived water contributes less in the backarc spreading ridge than in the arc (Peate et al. 2001). The enrichment of $\mathrm{Ba}$ in the seamounts north of $13^{\circ} \mathrm{N}$ (Fig. 21.5) is indicative of the metasomatism by injection of large amounts of fluids derived from the depleted mantle. In this study, the dehydration and dissolution of $\mathrm{Ba}$ and the other alkali and alkali-earth elements would explain the water and $\mathrm{Ba} / \mathrm{La}$ systematics.

Initial rifting of a backarc region most often occurs adjacent to the edge of the volcanic arc, because of concentration of tensional stress along the boundary of the arc crust (Stern et al. 1990). Between the MGR and the DSC sidescan sonar imagery shows high backscatter, numerous small volcanic cones and overlapping lobate flows, indicative of recent resurfacing by volcanism. This is similar to what is observed at the southern end of the Valu Fa ridge, where backarc spreading is propagating into the arc volcanic region (Peate et al. 2001). The most important change in magmatic activity that happens during the formation of a backarc basin is the transition from arc igneous activity to true sea-floor spreading and new lithosphere formation. Because arc magmas are constantly being generated deep in the mantle wedge throughout this process, and backarc opening initially occurs under the control of shallow tectonic stress (Gribble et al. 1998), there is an intermediate period of arc rifting in which magma sources may be influenced by these transitional tectonic phenomena. The FNVC would have been formed at such a tectonic setting. Never-the-less, it is important to mention that the sources of the studied rocks are related to back-arc formation but are not arc volcanoes.

\subsection{Conclusions}

The major and minor element chemistry and isotope characteristics of the backarc basin rocks from the southern end of Mariana Trough between $12^{\circ} 30$ and $13^{\circ} 30^{\prime} \mathrm{N}$ indicate a progression in interactions between two magmatic sources. The rocks of the backarc spreading center and nearby discrete chains of seamounts are formed mostly from the mantle wedge and have similar compositiosn: n-MORB-type mantle and depleted mantle. The former is the main source of the currently active spreading center, which has the morphology of a fast spreading ridge, such as the EPR, and the latter is the source of discrete seamounts that lie along two parallel chains between the spreading center ridge and the Mariana volcanic arc (FNVC and PMVC). The DSC (FNVC and PMVC) can be separated into two segments, one north of and one south of $13^{\circ} \mathrm{N}$. The chemical composition, especially the redox condition of the magmas differs by position north or south of $13^{\circ} \mathrm{N}$, not by distance from the active spreading center or the Mariana volcanic arc. The southern segment is more oxidizing than the northern segment, probably due to the depletion of more basic compositions.

We suggest that the center of active backarc extension in the southern Mariana Trough has migrated toward the southeast as the basin opened. The trench-arc system changes from an essentially N-S strike in the north and curves sharply westward at the southern end. The most recent backarc opening in the southernmost part of the Mariana Trough involves not only the active spreading center (MGR) but also the zone between it and an older chain of discrete seamounts (FNVC) This is consistent with southeastward roll-back of the descending slab as suggested by others (Martinez et al. 2000; Fryer et al. 2003; Gvirtzman and Stern 2004).

Acknowledgements The sample rocks for this study were collected during the cruises of R/Vs Yokosuka, Kairei and Hakuho-maru. Crews of those vessels and the operating teams of the Shinaki 6500 submersible and Kaiko ROV are gratefully acknowledged. We thank Dr. M. Kusakabe for guidance to water analyses, and Ms. K. Okazaki, Y. Akioka S. Matsumoto, T. Ueno, and D. Vonderhaar for assistance with the laboratory work, and Dr. K. Okino for providing the bathymetry map Drs. R. Stern and H. Sato are acknowledged for improvement of the manuscript with their review comments. This work was partly supported by the Scientific Fund of the Ministry of Education, Science and Culture (MEXT), Japan, to H. M. (\#20109006) This is SOEST contribution no. 9068 and HIGP contribution No. 2024.

Open Access This chapter is distributed under the terms of the Creative Commons Attribution Noncommercial License, which permits any noncommercial use, distribution, and reproduction in any medium, provided the original author(s) and source are credited. 


\section{References}

Baker N, Fryer P, Martinez F (1996) Rifting history of the Northern Mariana Backarc Basin, SeaMARC II and morphology studies. J Geophys Res 101(B5):11427-11455

Becker NC (2005) Recent volcanic and tectonic evolution of the southern Mariana arc, Dissertation, University of Hawai'i, ProQuest, UMI Dissertations Publishing, 2005. 3184487

Becker NC, Fryer P, Moore GF (2010) Malaguana-Gadao ridge: identification and implications of a magma chamber reflector in the southern Mariana Trough. Geochem Geophys Geosyst 11: Q04X13. doi:10.1029/2009GC002719

Bibee LD, Shor GG Jr, Lu RS (1980) Inter-arc spreading in the Mariana Trough. Mar Geol 35:183-197

Boettcher AL, O'Neil JR (1980) Stable isotope, chemical and petrographic studies of high-pressure amphiboles and micas: evidence for metasomatism in the mantle source regions of alkali basalts and kimberlites. Am J Sci 280A:594-621

Canil D (1999) Vanadium partitioning between orthopyroxene, spinel and silicate melt and the redox states of mantle source regions for primary magmas. Geochim Cosmochim Acta 63:557-572

Danyushevsky LV (2001) The effect of small amount of $\mathrm{H} 2 \mathrm{O}$ on crystallisation of mid-ocean ridge and backarc basin magmas. J Volcanol Geotherm Res 110:265-280

Eguchi T (1984) Seismotectonics around the Mariana Trough. Tectonophys 102:33-52

Embley RW, Baker ET, Chadwick WW, Lupton JE Jr, Resing JA, Massoth GJ, Nakamura K (2004) Explorations of Mariana arc volcanoes reveal new hydrothermal systems. EOS 85(4):37-44

Fryer P, Sinton JM, Philpotts JA (1981) Basaltic glasses from the Mariana Trough. In Init Rep Deep Sea Drill Proj 60:601-610; US Gov. Print. Office: Washington, DC

Fryer P, Fujimoto H, Sekine M, Johnson L, Kasahara J, Masuda H, Gamo T, Ishii T, Ariyoshi M, Fujioka K (1998) Volcanoes of the southwestern extension of the active Mariana island arc: new swathmapping and geochemical studies. Island Arc 7(3):596-607

Fryer P, Becker N, Appelgate B, Martinez F, Edwards M, Fryer G (2003) Why is the challenger deep is so deep? Earth Planet Sci Lett 211(3-4):259-269

Gamo T, The Shipboard Scientific Party of the Y9204 cruise (1993) Revisits to the mid-Mariana Trough hydrothermal site and discovery of new venting in the southern Mariana region by the Japanese submersible Shinkai 6500. InterRidge News 12:11-14

Gamo T, Tsunogai U, Ishibashi J, Masuda H, Chiba H (1997) Chemical characteristics of hydrothermal fluids from the Marina Trough. JAMSTEC J Deep Sea Res 69-74; special volume "Deep Sea Research in Subduction Zones, Spreading Centers and Backare Basins

Gamo T, Masuda H, Yamanaka T, Okamura K, Ishibashi J, Nakayama E, Obata H, Nishio K, Shitashima Y, Hasumoto H, Watanabe M, Mitsuzawa K, Seama N, Thusnogai U, Kouzuma F, Sano Y (2004) Discovery of a new hydrothermal venting site in the southernmost Mariana arc: al-rich plumes and white smoker activity associated with biogenic methane. Geochem J 38:527-534

Garcia MO, Lie NWK, Muenow DW (1979) Volatiles in submarine volcanic rocks from the Mariana island arc and Trough. Geochim Cosmochim Acta 43:305-312

Gribble RF, Stern RJ, Bloomer SH, Stüben D, O'Hearn T, Newman S (1996) MORB mantle and subduction components interact to generate basalts in the southern Mariana Trough backarc basin. Geochim Cosmochim Acta 60:2153-2166

Gribble RF, Stern RJ, Newman S, Bloomer SH, O’Hearn T (1998) Chemical and isotopic composition of lavas from the northern
Mariana Trough: implications for magmagenesis in back-arc basins. J Petrol 39:125-154

Gvirtzman Z, Stern RJ (2004) Bathymetry of Mariana trench-arc system and formation of the challenger deep as a consequence of weak plate coupling. Tectonics 23, TC2011. doi:10.1029/ 2003TC001581

Hart SR (1984) A large-scale isotope anomaly in the southern hemisphere mantle. Nature 309:753-757

Hart SR, Glassey WE, Karig DE (1972) Basalts and seafloor spreading behind the Mariana island arc. Earth Planet Sci Lett 15:12-18

Hawkesworth CJ, Gakkagher K, Hergt JM, McDermott F (1993) Mantle and slab contributions in arc magmas. Annu Rev Earth Planet Sci $21: 175-204$

Hawkins JW (1977) Petrology and geochemical characteristics of marginal basin basalt. In: Hayes DE (ed) Island arcs, deep sea trenches, and backarc basins, vol 23, Geophysics monograph series. AGU, Washington, DC, pp 355-365

Hawkins JW, Melchior JT (1985) Petrology of Mariana Trough and Lau Basin basalts. J Geophys Res 90:11431-11468

Hawkins JW, Lonsdale PF, Macdougall JD, Volpe AM (1990) Petrology of the axial ridge of the Mariana Trough backarc spreading center. Earth Planet Sci Lett 100:226-250

Hickey-Vargas R (1991) Isotope characteristics of submarine lavas from the Philippine sea: implications for the origin of arc and basin magmas of the Philippine plate. Earth Planet Sci Lett 107:290-304

Hirose K, Kawamoto T (1995) Hydrous partial melting of lherzorite at $1 \mathrm{Gps}$ - the effect of $\mathrm{H}_{2} \mathrm{O}$ on the genesis of basaltic magma. Earth Planet Sci Lett 133:463-473

Hussong DM, Uyeda S (1981), Tectonic processes and the history of the Mariana arc, a synthesis of the results of deep sea drilling project leg 60. In: Hussong DM, Uyeda S et al (eds) Initial reports of the deep sea drilling project 60, pp 909-929

Irvine TN, Baragar WRA (1971) A guide to the chemical classification of the common volcanic rocks. Can J Earth Sci 8:523-548

Ishibashi J, Yamanaka T, Kimura H, Hirota A, Toki T, Tsunigai U, Gamo T, Utsumi M, Roe K, Miyabe S, Okamura K (2004) Geochemistry of hydrothermal fluids in south Mariana backarc spreading center. EOS Trans AGU 85(47), Fall Meet Suppl, abstract V44A-03

Ishibashi J, Suzuki R, Yamanaka T, Toki T, Kimura H, Noguchi T, Urabe T (2006) Seafloor hydrothermal activity at off-axial seamounts of backarc spreading in southern Mariana Trough. Geochim Cosmochim Acta 70:A279

Jackson M (1989) Petrology and petrogenesis of recent submarine volcanics from the northern Mariana arc and back-arc basin, $\mathrm{PhD}$ Dissertation, University of Hawaii at Manoa, Honolulu, HI, United States (USA), 1989

Johnson L, Fryer P, Masuda H, Ishii T, Gamo T (1993) Hydrothermal vent deposits and two magma sources for volcanoes near $13^{\circ} 20^{\prime} \mathrm{N}$ in the Mariana backarc: a view from Shinkai 6500. EOS Trans AGU 74(43), Fall Meet Suppl., abstract V51C-14

Karig DE (1971) Structural history of the Mariana Island arc system. Geol Soc Am Bull 82:323-344

Kasahara J, Sato T, Fujioka K (1994) Intensive thermal upwelling at a seamount in the southern Mariana Trough observed by ocean bottom seismic instruments using "Shinkai 6500" submersible. JAMSTEC J Deep Sea Res 10:163-174

Kato T, Beavan J, Matsushima T, Karato Y, Camacho J, Nakao S (2003) Geodesic evidence of backarc spreading in the Mariana Trough. Geophys Res Lett 30(27-1):1625. doi:10.1029/2002GL016757

Kitada K, Seama N, Yamazaki T, Nogi Y, Suyehiro K (2006) Distinct regional differences in crustal thickness along the axis of the Mariana Trough, inferred from gravity anomalies. Geochem Geophys Geosyst 7:Q04011. doi:10.1029/2005GC001119

Kyser TK, O’Neil JR (1984) Hydrogen isotope systematics of submarine basalts. Geochim Cosmochim Acta 48:2123-2133 
Lin PN, Stern RJ, Bloomer SH (1989) Shoshoniitic volcanism in the northern Mariana arc, 2: large-ion lithophile and rare earth element abundances: evidence for the source of incompatible elemet enrichments in intraoceanic arcs. J Geophys Res 94:4497-4514

Macdonald GA (1968) Composition and origin of Hawaiian lavas. In: Coats RR, Hay RL, Anderson CA (eds) Studies in volcanology: a Memoir in honor of Howel Williams. Geol Soc Am Mem 116

Macpherson CG, Hilton DR, Mattey DP, Sinton JM (2000) Evidence for an ${ }^{18} \mathrm{O}$-depleted mantle plume from contrasting ${ }^{18} \mathrm{O} /{ }^{16} \mathrm{O}$ ratios of backarc lavas from the Manus Basin and Mariana Trough. Earth Planet Sci Lett 176:171-183

Martinez F, Fryer P, Baker N, Yamazaki T (1995) Evolution of backarc rifting: Mariana Trough, $20^{\circ} \mathrm{N}-24^{\circ} \mathrm{N}$. J Geophys Res 100:3807-3827

Martinez F, Fryer P, Becker N (2000) Geophysical characteristics of the southern Mariana Trough, $11^{\circ} 50^{\prime} \mathrm{N}-13^{\circ} 40^{\prime} \mathrm{N}, J$. Geophys Res 105:16591-16607

Masuda H, Gamo T, Fryer P, Ishii T, Johnson LE, Tanaka H, Tsunogai U, Matsumoto S, Masumoto S, Fujioka K (1993) Relationship between volcanisms and topography from the major element rock chemistry in the southern Mariana Trough. JAMSTEC J Deep Sea Res 9:181-189 (Japanese with English abstract)

McCulloch MT, Gamble JA (1991) Geochemical and geodynamical constraints on subduction zone magmatism. Earth Planet Sci Lett 102:358-374

Mitsuzawa K, Masuda H, Seama N, Hasegawa Y, Miyamoto M, Togashi N, So A, Yamanobe H (2000) Preliminary report of deeptow/Yokosuka cruise at hydrothermal areas in the mid and southern Mariana. JAMSTEC Deep Sea Res 17:73-87 (Japanese with English abstact)

Natland JH, Tarney J (1981) Petrologic evolution of the Mariana arc and backarc basin system - a synthesis of drilling results in the south Philippine Sea. In: Hussong DM, Uyeda S (eds) Init Repts DSDP, vol 60. U. S. Govt Printing Office, Washington DC, pp 877-907

Parkinson IJ, Arculus RJ (1999) The redox state of subduction zones: insights from arc-peridotites. Chem Geol 160:409-423

Pearce JA, Stern RJ, Bloomer S, Fryer P (2005) Geochemical mapping of the Mariana arc-basin system: implications for the nature and distribution of subduction components. Geochem Geophys Geosyst 6, Q07006. doi:10.1029/2004GC000895

Peate DW, Kokfelt TF, Hawkesworth CJ, van Calsteren PW, Hergt JM, Pearce JA (2001) U-series isotope data on Lau Basin glasses: the role of subduction-related fluids during melt generation in backarc basins. J Petrol 42:1449-1470

Plank T, Langmuir C (1998) The chemical composition of subducting sediment and its consequence for the crust and mantle. Chem Geol 145:325-394

Poreda R (1985) Helium-3 and deuterium in backarc basalts: Lau Basin and the Mariana Trough. Earth Planet Sci Lett 73:244-254

Ribeiro JM, Stern RJ, Martinez F, Ishizuka O, Merle SG, Kelley K, Anthony EY, Ren M, Ohara Y, Reagan M, Girard G, Bloomer S (2013a) Geodynamics evolution of a forearc rift in the southernmost Mariana arc. Island Arc. doi:10.111/iar.12039

Ribeiro JM, Stern RJ, Kelley K, Martinez F, Ishizuka O, Manton SWI, Ohara Y (2013b) Nature and distribution of slab-derived fluids and mantle sources beneath the Southeast Mariana forearc rift. Geochem Geophys Geosyst. doi:10.1002/ggge.20244

Seama N, Hasegawa Y, Nakase K, Mitsuzawa K, Masuda H, Yamazaki $\mathrm{T}$ (2001) Tectonic evolution of central and southern Mariana Trough, 2001 Joint Meeting of Earth and Planetary Science, Abstract A5-001, Tokyo

Sheppard SMF, Harris C (1985) Hydrogen and oxygen isotope geochemistry of Ascension Island lavas and granites: variation with crystal fractionation and interaction with seawater. Contrib Min Petrol 91:74-81

Shervais JW (1982) Ti-V plots and the petrogenesis of modern and ophiolitic lavas. Earth Planet Sci Lett 59:101-118

Sinton JM, Fryer P (1987) Mariana Trough lavas from $18^{\circ} \mathrm{N}$ : implications for the origin of back arc basin basalts. J Geophys Res 92:12782-12802

Sinton JM, Ford LL, Chappell B, McCulloch MT (2003) Magma genesis and mantle heterogeneity in the Manus backarc basin, Pupua New Guinea. J Petrol 44:159-195

Smoot NC (1990) Mariana Trough by multi-beam sonar. Geo-Mar Lett 10:137-144

Stern RJ, Lin P-N, Morris JD, Jackson MC, Fryer P, Bloomer SH, Ito E (1990) Enriched backarc basalts from the northern Mariana Trough: implications for the magmatic evolution of backarc basins. Earth Planet Sci Lett 100:210-225

Stern RJ, Jackson MC, Fryer P, Ito E (1993) O, Sr, Nd and Pb isotopic composition of Kasuga Cross-Chain in the Mariana Arc: a new perspective on the $\mathrm{k}-\mathrm{h}$ relationship. Earth Planet Sci Lett 119:459-475

Stern RJ, Tamura Y, Masuda H, Fryer P, Martinez F, Ishizuka O, Bloomer SH (2013) How the Mariana volcanic arc ends in the south. Island Arc 22:133-148

Stolper EM, Newman S (1992) Fluids in the source regions of subduction zone magmas: clues from the study of volatiles in Mariana Trough magmas. Rept Geol Surv Jpn 279:161-169

Stolper EM, Newman S (1994) The role of water in the petrogenesis of Mariana Trough magmas. Earth Planet Sci Lett 121:293-325

Sun S.-S., and W. F. McDonough (1989) Chemical and isotopic systematics of oceanic basalts: Implications for mantle composition and processes. In: Sanders AD, Norry MJ (eds) Magmatism in the ocean basins. Geol Soc London Spec Publ, 42, pp 313-345

Sun S-S, Nesbit RW, Sharaskin AY (1979) Geochemical characterisitcs of mid-ocean ridge basalts. Earth Planet Sci Lett 44:119-138

Taylor B, Martinez F (2003) Back-arc basalt systematics. Earth Planet Sci Lett 210:481-497

Utsumi M, Nakamura K, Kakegawa T, Shitashima K, Kurusu Y, Yamanaka H, Takano Y, Kimura H, Higashi Y, Ishibashi J, Hirota A, Kaneko R, Minabe M, Kasai H, Settsu M (2004) First discovery of hydrothermal vent with black smoker (Pika site) at the southern Mariana Region and its properties, 2004 Joint Meeting of Earth and Planetary Science, Abstract B002-016, Chiba

Volpe AM, MacDougall D, Lugmair GW, Hawkins JW, Lonsdale P (1990) Fine-scale isotopic variation in Mariana Trough basalts: evidence for heterogeneity and a recycled component in backarc basin mantle. Earth Planet Sci Lett 100:251-264

Vople AM, MacDougall JD, Hawkins JW (1987) Mariana Trough basalts (MTB): trace element and $\mathrm{Sr}-\mathrm{Nd}$ isotopic evidence for mixing between n-MORB-like and Arc-like melts. Earth Planet Sci Lett 82:241-254

Yamatani Y, Masuda H, Amakawa H, Nazaki Y, Gamo T (1994) Rare earth element chemistry of submarine valcanic rocks from a spreading axis, the southern Mariana Trough. JAMSTECJ Deep Sea Res 10:187-193 (Japanese with English abstract)

Yamazaki T, Stern RJ (1997) Topography and magnetic vector anomalies in the Mariana Trough. JAMSTEC J Deep Sea Res 13:31-45

Yamazaki T, Murakami F, Saito E (1993) Mode of seafloor spreading in the northern Mariana Trough. Tectonophys 221:208-222

Yoshikawa S, Okino K, Asada M (2012) Geomorphology variations at hydrothermal sites in the southern Mariana Trough: relationship between hydrothermal activity and topographic characteristics. Mar Geol 303-306:172-182 